\title{
Gambaran Fungsi Hati pada Sepsis Neonatorum di RSUP Prof. Dr. R. D. Kandou Manado
}

\section{Lorencia, ${ }^{1}$ Jeanette I. Ch. Manoppo, ${ }^{2}$ Valentine Umboh ${ }^{2}$}

\author{
${ }^{1}$ Program Studi Pendidikan Dokter Fakultas Kedokteran Universitas Sam Ratulangi Manado \\ ${ }^{2}$ Bagian Ilmu Kesehatan Anak Fakultas Kedokteran Universitas Sam Ratulangi Manado \\ Email: latuharil@gmail.com
}

\begin{abstract}
Neonatal sepsis is a clinical syndrome that consists of nonspecific symptoms and infection signs, occuring with bacteremia in the first 28 days of life. SGOT and SGPT abnormalities as well as hypoalbuminemia can be found in neonatal sepsis patients. This study was aimed to obtain the overview of liver function especially SGOT, SGPT and albumin in neonatal sepsis patients at NICU of Prof. Dr. R. D. Kandou Hospital. This was a retrospective and descriptive study. Data were obtained from the patients' medical records. The results showed that the percentage of sepsis patients that had mild increased SGOT level was $47.9 \%$. Meanwhile, the SGPT level was more often normal (81.7\%). Hypoalbuminemia was found in 54 patients $(76.1 \%)$, more frequent in male infants $(80.9 \%)$. Increased SGOT and SGPT levels were more frequent in male infants; $51.1 \%$ for mild increased SGOT and $12.8 \%$ for mild increased SGPT. In conclusion, among neonatal sepsis increased SGOT levels were more often in mild form meanwhile increased SGPT levels were rare. Increased SGOT and SGPT levels and decreased albumin levels were more common among male infants.
\end{abstract}

Keywords: SGOT, SGPT, albumin, neonatal sepsis

\begin{abstract}
Abstrak: Sepsis neonatorum merupakan sindroma klinis yang terdiri dari gejala-gejala nonspesifik dan tanda-tanda infeksi, terjadi bersamaan dengan bakteremia pada 28 hari pertama kehidupan. Abnormalitas SGOT dan SGPT serta hipoalbuminemia dapat ditemukan pada pasien sepsis neonatorum. Penelitian ini bertujuan untuk mengetahui gambaran fungsi hati secara khusus SGOT, SGPT, dan albumin pada pasien sepsis neonatorum di NICU RSUP Prof. Dr. R.D. Kandou. Jenis penelitian ialah deskriptif retrospektif menggunakan data rekam medik pasien sepsis neonatorum. Hasil penelitian mendapatkan persentase pasien sepsis yang mengalami peningkatan ringan kadar SGOT sebesar 47,9\%. Kadar SGPT lebih sering ditemukan normal $(81,7 \%)$. Hipoalbuminemia dijumpai pada 54 pasien $(76,1 \%)$, lebih sering pada bayi laki-laki $(80,9 \%)$. Peningkatan SGOT dan SGPT berdasarkan jenis kelamin lebih sering pada bayi laki-laki dan dalam bentuk peningkatan ringan yaitu sebesar $51,1 \%$ untuk SGOT dan $12,8 \%$ untuk SGPT. Simpulan penelitian ini ialah pada pasien sepsis neonatorum peningkatan kadar SGOT paling sering dalam bentuk peningkatan ringan sedangkan peningkatan kadar SGPT jarang didapatkan. Peningkatan ringan SGOT dan SGPT serta penurunan albumin lebih sering dijumpai pada bayi laki-laki.
\end{abstract}

Kata kunci: SGOT, SGPT, albumin, sepsis neonatorum

\section{PENDAHULUAN}

Sepsis neonatorum merupakan sindroma klinis yang terdiri dari gejala-gejala nonspesifik dan tanda-tanda infeksi, terjadi bersamaan dengan bakteremia pada 28 hari pertama kehidupan. ${ }^{1}$ Sepsis neonatorum merupakan penyebab utama mortalitas dan morbiditas jangka panjang pada neonatus. Insidensi sepsis neonatorum bervariasi dari 1-4 kejadian per 1000 kelahiran hidup di negara maju dan 10-50 kejadian per 1000 kelahiran hidup di negara berkembang. ${ }^{2}$ 
Organisasi kesehatan dunia (WHO) melaporkan bahwa pada tahun 2016 penyebab kematian pada anak di bawah 5 tahun, khususnya periode neonatal, $7 \%$ disebabkan oleh sepsis neonatorum. ${ }^{3}$ Angka mortalitas akibat sepsis neonatorum cukup tinggi, terutama di negara berkembang. Di Indonesia, Riset Kesehatan Dasar (Riskesdas) tahun 2007 melaporkan bahwa sebanyak $20,5 \%$ dari penyebab kematian bayi usia 7-28 hari disebabkan oleh sepsis neonatorum. ${ }^{4}$ Pada tahun 2017 di Kota Manado, angka kematian neonatal ialah 9 kematian, salah satu penyebabnya ialah sepsis. ${ }^{5}$

Sepsis neonatorum merupakan masalah yang amat serius. Respon imun yang adekuat diperlukan untuk menghentikan infeksi dan mencegah penyebaran infeksi tersebut dalam tubuh hospes, namun jika inflamasi yang terjadi tidak dibatasi dan menyebar ke seluruh tubuh, hal itu mengakibatkan sekumpulan tanda dan gejala yang disebut systemic inflammatory response syndrome (SIRS). Jika infeksi tak dapat dihentikan, patogen dari tempat infeksi lokal akan menyebar ke dalam darah dan mengakibatkan aktivasi endotel sistemik serta memresipitasi sepsis, yang kemudian akan menjadi lebih parah dan terjadi syok sepsis. Proses berkembangnya sepsis ke syok sepsis dapat mengarah pada sindroma disfungsi organ multipel (multiple organ dysfunction syndrome/MODS) yang mengakibatkan prognosis menjadi kurang baik. Curah jantung yang tidak adekuat serta kegagalan mikrosirkulasi akan membuat perfusi jaringan ke organorgan seperti ginjal, usus, sistem saraf pusat, maupun hati menjadi terganggu. ${ }^{6}$

Disfungsi hati merupakan salah satu dari komponen MODS dan biasanya merupakan penanda prognosis yang buruk. Hati memainkan peran penting dalam berbagai aktivitas metabolik, homeostasis, dan pertahanan pejamu. Disfungsi hati umumnya dilihat hanya sebagai konsekuensi syok dan hipoperfusi jaringan awal, namun faktanya cedera pada hati merupakan salah satu faktor utama dalam permulaan dan amplifikasi kegagalan organ multipel. ${ }^{7}$ Insidensi disfungsi hati rerata pada pasien dengan sepsis ialah $39,9 \%$, lebih rendah daripada insidensi gangguan pada organ lain terkait sepsis seperti paru-paru, ginjal, otak, kardiovaskular, dll. Meskipun demikian disfungsi dan gagal hati dihubungkan dengan komplikasi yang parah pada pasien sepsis. Angka kematian pada pasien disfungsi hati terkait sepsis berkisar antara 54\%-68\%, lebih tinggi daripada pasien sepsis dengan gangguan pernapasan. Data ini membuktikan bahwa hati berperan penting dalam kelangsungan hidup dan pemulihan pasien pasca cedera sepsis. ${ }^{8}$ Khalil et al $^{9}$ dalam penelitian observasional prospektif yang dilakukan terhadap 153 neonatus yang terbukti sepsis berdasarkan kultur darah mendapatkan bahwa disfungsi hati sangat umum dijum-pai pada awal sepsis neonatorum, paling sering dalam bentuk cholestatic jaundice $(42,5 \%)$ dan alanine aminotransferase (ALT) yang meningkat sebanyak $37,3 \%$.

Pemeriksaan fungsi hati yang biasa dilakukan untuk mengukur kerusakan hati ialah liver function test. Abnormalitas dari enzim-enzim hati seperti serum glutamic oxaloacetic transaminase (SGOT) dan serum glutamic pyruvic transaminase (SGPT) yang meningkat dua kali lipat dari batas normal dapat ditemukan pada pasien sepsis neonatorum yang mengalami disfungsi hati. ${ }^{7,9}$ Penelitian yang dilakukan oleh Adiga ${ }^{10}$ menunjukkan kadar SGOT (AST) yang lebih rendah pada perempuan dibandingkan laki-laki. Variasi perbedaan hasil enzim hati pada kedua jenis kelamin sering dikaitkan dengan faktor hormonal. Hipoalbuminemia juga sering dijumpai pada pasien neonatus yang mengalami sepsis. Kurangnya kadar albumin serum sering dikaitkan dengan prognosis yang buruk. $^{11}$

Berdasarkan latar belakang yang telah diuraikan, penulis tertarik untuk mengetahui gambaran fungsi hati pada pasien sepsis neonatorum di NICU RSUP Prof. Dr. R. D. Kandou khususnya SGOT, SGPT dan albumin periode 2014-2019 secara umum dan berdasarkan jenis kelamin. 


\section{METODE PENELITIAN}

Penelitian ini dilakukan untuk mengetahui gambaran fungsi hati pada pasien sepsis neonatorum. Jenis penelitian ialah deskriptif retrospektif dan sumber data yang digunakan berasal dari rekam medik pasien. Penelitian dilakukan sejak bulan September 2019-November 2019. Kriteria inklusi pada penelitian ini ialah pasien sepsis neonatorum yang memiliki rekam medik lengkap dan yang melakukan pemeriksaan laboratorium fungsi hati (SGOT, SGPT, dan albumin).

Pada penelitian ini, fungsi hati dinilai melalui tes fungsi hati, secara khusus albumin, SGOT dan SGPT, yang diperoleh melalui rekam medik. Nilai normal SGOT ialah <33 U/L dan SGPT ialah <43 U/L. Peningkatan SGOT dan SGPT dibagi menjadi peningkatan ringan ( $<3$ kali normal), peningkatan sedang (3-10 kali normal), dan peningkatan berat ( $>10$ kali normal). ${ }^{12,13}$ Kadar normal albumin neonatus ialah 3,5$5,0 \mathrm{~g} / \mathrm{dL}$ dan dinyatakan hipoalbuminemia jika kadar albumin $<3,5 \mathrm{~g} / \mathrm{dL}$.

Data pasien yang dicatat meliputi identitas berupa nama, jenis kelamin, umur, usia gestasi dan tanggal masuk beserta data albumin, AST (SGOT) dan ALT (SGPT) dari rekam medik. Data penelitian diolah dan disajikan dalam bentuk tabel distribusi frekuensi.

Penelitian ini telah mendapat persetujuan dari Komisi Etik Penelitian Kesehatan RSUP Prof. Dr. R. D. Kandou Manado, dengan nomor keterangan layak etik yaitu No. 058/EC/KEPK-KANDOU/X/2019.

\section{HASIL PENELITIAN}

Pada penelitian ini didapatkan 71 sampel yang memenuhi kriteria inklusi yaitu pasien sepsis neonatorum yang melakukan pemeriksaan SGOT, SGPT dan albumin.

Tabel 1 memperlihatkan sebanyak 47 $(66,2 \%)$ pasien sepsis neonatorum yang berjenis kelamin laki-laki dan sisanya sebanyak $24(33,8 \%)$ pasien berjenis kelamin perempuan. Bayi dengan usia gestasi >37 minggu (BCB-SMK) yang mengalami sepsis berjumlah 43 pasien $(60,6 \%)$; yang memiliki usia gestasi $<37$ minggu sebanyak 27 pasien $(38,0 \%)$; dan yang cukup bulan (>37 minggu) namun kecil masa kehamilan (BCB-KMK) berjumlah 1 pasien $(1,4 \%)$. Usia bayi yang mengalami sepsis neonatorum paling banyak berusia 0-3 hari sebanyak 55 pasien $(77,5 \%)$ dan untuk usia 4-28 hari, terdapat sebanyak 16 pasien $(22,5 \%)$.

Tabel 1. Karakteristik sampel penelitian

\begin{tabular}{ccc}
\hline & n & \% \\
\hline Jenis Kelamin & & \\
Laki-laki & 47 & 66,2 \\
Perempuan & 24 & 33,8 \\
Usia gestasi & & \\
BCB-SMK & 43 & 60,6 \\
BKB-SMK & 27 & 38,0 \\
BCB-KMK & 1 & 1,4 \\
Usia & & \\
0-3 hari & 55 & 77,5 \\
4-28 hari & 16 & 22,5 \\
\hline
\end{tabular}

Tabel 2 memperlihatkan dari 71 pasien sepsis neonatorum, $51 \quad(71,8 \%)$ pasien mengalami peningkatan SGOT tersering peningkatan ringan $(47,9 \%)$ sedangkan 20 pasien $(28,2 \%)$ sisanya memiliki SGOT normal. Pada pemeriksaan serum glutamic pyruvic transaminase (SGPT), sebanyak 13 pasien $(18,3 \%)$ mengalami peningkatan tersering peningkatan ringan $(9,9 \%)$ sedangkan 58 pasien $(81,7 \%)$ lainnya normal. Yang mengalami penurunan albumin berjumlah 54 pasien $(76,1 \%)$ sedangkan yang memiliki kadar albumin normal sebanyak 17 pasien $(23,9 \%)$.

Tabel 3 memperlihatkan bahwa dari 47 pasien yang berjenis kelamin laki-laki didapatkan 36 pasien $(76,6 \%)$ yang mengalami peningkatan SGOT tersering peningkatan ringan $(51,1 \%)$ sedangkan 11 pasien $(23,4 \%)$ lainnya memiliki nilai SGOT normal. Dari 24 pasien sepsis neonatorum yang berjenis kelamin perempuan didapatkan 15 pasien $(62,5 \%)$ mengalami peningkatan kadar SGOT tersering peningkatan ringan $(41,7 \%)$ sedangkan 9 pasien $(37,5 \%)$ memiliki nilai SGOT normal.

Tabel 4 memperlihatkan dari 47 pasien laki-laki yang melakukan pemeriksaan SGPT didapatkan 10 pasien $(21,3 \%)$ 
mengalami peningkatan SGPT tersering peningkatan ringan $(12,8 \%)$ sedangkan 37 pasien $(78,7 \%)$ lainnya memiliki kadar SGPT normal. Dari total 24 pasien sepsis neonatorum berjenis kelamin perempuan didapatkan 3 pasien $(12,5 \%)$ mengalami peningkatan SGPT tersering peningkatan sedang $(8,3 \%)$ sedangkan 21 pasien $(87,5 \%)$ memiliki kadar SGPT normal.

Tabel 5 memperlihatkan berdasarkan jenis kelamin laki-laki nilai albumin menurun pada 38 pasien $(80,9 \%)$ dari total keseluruhan 47 pasien; 9 pasien $(19,1 \%)$ lainnya memiliki nilai albumin normal. Pasien perempuan yang mengalami sepsis neonatorum ialah 24 bayi; 16 pasien $(66,7 \%)$ mengalami penurunan kadar albumin, sisanya berjumlah 8 pasien $(33,3 \%)$ mempunyai kadar albumin dalam batas normal.
Tabel 2. Hasil laboratorium pasien sepsis neonatorum

\begin{tabular}{ccc}
\hline & n & \% \\
\hline SGOT & & \\
Meningkat & & \\
Ringan (<3 kali normal) & 34 & 47,9 \\
Sedang (3-10 kali normal) & 12 & 16,9 \\
Berat (>10 kali normal) & 5 & 7 \\
Normal & 20 & 28,2 \\
SGPT & & \\
Meningkat & & \\
Ringan (<3 kali normal) & 7 & 9,9 \\
Sedang (3-10 kali normal) & 5 & 7,0 \\
Berat (>10 kali normal) & 1 & 1,4 \\
Normal & 58 & 81,7 \\
Albumin & & \\
Menurun & 54 & 76,1 \\
Normal & 17 & 23,9 \\
\hline
\end{tabular}

Tabel 3. Nilai SGOT berdasarkan jenis kelamin

\begin{tabular}{ccc}
\hline \multirow{2}{*}{ SGOT } & \multicolumn{2}{c}{ Jenis kelamin } \\
& Laki-laki n(\%) & Perempuan $n(\%)$ \\
\hline Normal & $11(23,4)$ & $9(37,5)$ \\
Meningkat & & \\
Ringan $(<3$ kali normal) & $24(51,1)$ & $10(41,7)$ \\
Sedang (3-10 kali normal) & $8(17,0)$ & $4(16,7)$ \\
Berat $(>10$ kali normal) & $4(8,5)$ & $1(4,1)$ \\
Total & $47(100)$ & $24(100)$ \\
\hline
\end{tabular}

Tabel 4. Nilai SGPT berdasarkan jenis kelamin

\begin{tabular}{ccc}
\hline \multirow{2}{*}{ SGPT } & \multicolumn{2}{c}{ Jenis kelamin } \\
& Laki-laki n (\%) & Perempuan n (\%) \\
\hline Normal & $37(78,7)$ & $21(87,5)$ \\
Meningkat & & \\
Ringan (<3 kali normal) & $6(12,8)$ & $1(4,2)$ \\
Sedang (3-10 kali normal) & $3(6,4)$ & $2(8,3)$ \\
Berat (>10 kali normal) & $1(2,1)$ & $0(0,0)$ \\
Total & $47(100)$ & $24(100)$ \\
\hline
\end{tabular}

Tabel 5. Nilai abumin berdasarkan jenis kelamin

\begin{tabular}{ccc}
\hline \multirow{2}{*}{ Albumin } & \multicolumn{2}{c}{ Jenis kelamin } \\
& $\begin{array}{c}\text { Laki-laki } \\
\mathrm{n}(\%)\end{array}$ & $\begin{array}{c}\text { Perempuan } \\
\mathrm{n}(\%)\end{array}$ \\
\hline Normal & $9(19,1)$ & $8(33,3)$ \\
Menurun & $38(80,9)$ & $16(66,7)$ \\
Total & $47(100)$ & $24(100)$ \\
\hline
\end{tabular}




\section{BAHASAN}

Dalam penelitian ini, sepsis neonatorum lebih sering terjadi pada jenis kelamin laki-laki daripada perempuan. Hal ini sejalan dengan penelitian yang dilakuan di NICU Rumah Sakit Cipto Mangunkusumo yang melaporkan dari total 138 pasien sepsis neonatorum yang dirawat, didapatkan $80(58,2 \%)$ pasien berjenis kelamin laki-laki dan $58(42,0 \%)$ sisanya berjenis kelamin perempuan. ${ }^{14}$ Meshram et $\mathrm{al}^{15}$ juga memperoleh hasil demikian, dari 455 neonatus yang terdiagnosis sepsis, didapatkan sebanyak $278(61,10 \%)$ berjenis kelamin laki-laki, sisanya berjenis kelamin perempuan. Hasil yang selaras juga dilaporkan oleh Kumar et $\mathrm{al}^{16}$ dan Roeslani et al $^{17}$ yang mendapatkan jumlah pasien sepsis neonatorum berjenis kelamin laki-laki lebih sering daripada yang berjenis kelamin perempuan. Prevalensi pasien sepsis neonatorum berjenis kelamin lakilaki pada penelitian Kumar et $\mathrm{al}^{16}$ berjumlah $117(66,85 \%)$ dari total 175 pasien sepsis neonatorum dan pada penelitian Roeslani el $\mathrm{al}^{17}$ persentase pasien sepsis neonatorum berjenis kelamin laki-laki sebesar 57,8\%. Jenis kelamin laki-laki dikatakan menjadi salah satu faktor risiko terjadinya sepsis neonatorum. Neonatus berjenis kelamin laki-laki lebih sensitif terhadap kondisi lingkungan perinatal dan postnatal yang merugikan, dan lebih mungkin dilahirkan prematur dengan berat lahir yang lebih rendah (BBLR); kedua hal ini juga merupakan faktor risiko kejadian sepsis neonatal. ${ }^{6,18}$ Kondisi tersebut dipengaruhi oleh faktor-faktor pengatur sintesis gammaglobulin yang terletak pada kromosom X. Laki-laki hanya memiliki satu kromosom $\mathrm{X}$ sedangkan perempuan memi-liki dua kromosom $\mathrm{X}$; hal ini yang membuat proteksi imunologis pada bayi laki-laki lebih rendah dibandingkan perempuan. ${ }^{19,20}$

Berdasarkan usia gestasi dalam penelitian ini, jumlah neonatus yang mengalami sepsis lebih tinggi untuk bayi cukup bulan (37-42 minggu). Hal ini sejalan dengan hasil penelitian yang dilakukan oleh Dini et $\mathrm{al}^{21}$ di RSUD Ulin Banjarmasin. Dari 42 bayi yang mengalami sepsis neonatorum,
$17(40,48 \%)$ merupakan bayi dengan masa gestasi berisiko tinggi ( $<37$ minggu atau $>42$ minggu) dan lebih sering yaitu sebanyak $25(59,52 \%)$ neonatus dengan sepsis merupakan bayi dengan masa gestasi berisiko rendah (37-42 minggu). Jumlah yang berbeda diperoleh pada penelitian Jaya et $\mathrm{al}^{20}$ yang mendapatkan jumlah pasien prematur yang mengalami sepsis neonatorum sebanyak 14 dari 20 pasien. Pada penelitian yang dilakukan oleh Kardana $^{2}$ didapatkan persentase pasien sepsis neonatorum yang lahir prematur sebesar 50,7\%, sedikit lebih tinggi daripada neonatus yang terlahir dengan masa gestasi cukup bulan. Prematuritas sering dikaitkan dengan kejadian sepsis neonatorum. Hal ini terjadi karena sistem imun pada bayi prematur baik seluler maupun humoral belum bekerja dengan baik. Pada trimester akhir kehamilan terjadi transpor pasif imunoglobulin ke sirkulasi fetal sehingga bayi prematur memiliki imunoglobulin yang rendah dan lebih rentan mengalami infeksi bahkan sampai sepsis. Bayi prematur juga membutuhkan perawatan lebih lama di rumah sakit; hal ini membuka celah terjadinya infeksi nosokomial yang juga bisa berkembang menjadi sepsis neonatorum. ${ }^{20,21}$ Roeslani et $\mathrm{al}^{17}$ menyimpulkan dalam penelitiannya bahwa prematuritas merupakan faktor risiko independen terhadap terjadinya sepsis neonatorum awitan dini. Pada penelitian ini, didapatkan hasil pasien sepsis neonatorum lebih sering dengan masa gestasi cukup bulan; hal ini bisa saja berhubungan dengan faktor-faktor risiko lain terhadap terjadinya sepsis neonatorum yang beragam, dan bukan hanya prematuritas.

Gambaran umum serum glutamic oxaloacetic transaminase (SGOT) pada penelitian ini memperlihatkan sebanyak 51 $(71,8 \%)$ pasien mengalami kenaikan SGOT, 34 (47,9\%) mengalami peningkatan SGOT ringan, $12(16,9 \%)$ sedang dan 5 (7\%) berat, $20(28,2 \%)$ sampel memiliki kadar SGOT normal. Penelitian yang dilakukan oleh Shah et $\mathrm{al}^{22}$ mendapatkan bahwa sepsis $(n=123)$ merupakan penyebab tersering meningkatnya enzim hati. 
Salah satu manifestasi dari disfungsi hati akibat sepsis ialah kolestasis yang diinduksi sepsis, dan kadar SGOT dan SGPT yang meningkat dapat ditemukan pada keadaan ini. Penelitian yang dilakukan oleh Karyana et al $^{23}$ di RSUP Sanglah Denpasar mendapatkan prevalensi kolestasis pada sepsis neonatorum sebesar 38,9\%. Kolestasis pada sepsis terjadi akibat terganggunya fungsi transpor asam empedu, pelepasan produk mikroba seperti endotoksin bakteri mengakibatkan teraktivasinya sitokin-sitokin proinflamasi yang membuat terhambatnya transpor anion-anion organik pada sinusoid maupun membran kanalikuli hepatosit. Hal ini mengganggu fungsi hepatosit dalam penggunaan maupun ekskresi asam empedu sehingga menimbulkan kerusakan sel-sel hati akibat tertahannya bahan-bahan yang seharusnya disekresikan ke duodenum. ${ }^{23-25}$ Bachtiar et al ${ }^{14}$ menunjukkan bahwa kadar rerata AST, ALT, dan $\gamma$ GT pada 91 neonatus yang terbukti kolestasis pada sepsis berada pada kisaran normal di awal terjadinya kolestasis. SGOT tidak hanya terdapat pada jaringan hati namun terdapat juga pada jaringan lain seperti jantung, ginjal, otot lurik, dan peningkatan SGOT pada sepsis neonatorum dapat dihubungkan dengan reaksi inflamasi berlebih yang kemudian mengakibatkan cedera hepatoseluler. $^{26,27}$ Pada peningkatan SGOT berdasarkan jenis kelamin, didapatkan bahwa bayi laki-laki lebih banyak mengalami peningkatan SGOT yaitu sebanyak 36 pasien $(76,6 \%)$ mengalami peningkatan SGOT, lebih sering dalam bentuk peningkatan ringan. Pada bayi perempuan $15(62,5 \%)$ dari 24 pasien mengalami peningkatan kadar SGOT, di antaranya $10(41,7 \%)$ ialah peningkatan ringan. Prevalensi sepsis neonatorum berdasarkan jenis kelamin yang mengalami kadar SGOT abnormal belum pernah diteliti, namun beberapa penelitian seperti penelitian yang dilakukan oleh Adiga $^{10}$ menunjukkan kadar SGOT (AST) yang lebih rendah pada perempuan dibandingkan laki-laki. Variasi perbedaan hasil enzim hati pada kedua jenis kelamin sering dikaitkan dengan faktor hormonal. Dinar- shanty et $\mathrm{al}^{28}$ dalam penelitiannya yang bertujuan mengetahui kadar TNF- $\alpha$ dan IL6 terhadap kejadian gagal hati akut pada pasien sepsis neonatorum awitan dini (SNAD), mendapatkan bahwa kadar TNF$\alpha$ dan IL-6 berkorelasi positif terhadap nilai SGOT, SGPT, dan rasio SGOT/SGPT pada sepsis neonatorum awitan dini. TNF $\alpha$ dan IL-6- sendiri merupakan mediator endogen yang berperan dalam patofisiologi sepsis neonatorum, Angele et $\mathrm{al}^{29}$ mengemukakan bahwa IL-6 sebagai mediator pro inflamasi mengalami peningkatan bermakna pada laki-laki dibandingkan dengan perempuan pada sepsis.

Kadar serum glutamic pyruvic transaminase (SGPT) neonatus pada penelitian ini memperlihatkan $58(81,7 \%)$ neonatus memiliki kadar SGPT normal dan yang mengalami peningkatan sebanyak 13 neonatus $(18,3 \%)$, paling sering peningkatan ringan $(9,9 \%)$. Disfungsi hati merupakan salah satu komponen multiple organ dysfunction syndrome yang jarang terjadi, SGPT sendiri merupakan salah satu biomarker pemeriksaan hati yang spesifik karena secara khusus memiliki konsentrasi yang tinggi pada hepar dan konsentrasi sangat rendah pada jaringan lainnya. ${ }^{27,30}$ Wang et $\mathrm{al}^{31}$ dalam hal sepsis dan gangguan fungsi hati menyatakan bahwa pada saat sepsis akan terjadi gangguan mikrosirkulasi maupun sistemik, serta pelepasan sitokin-sitokin proinflamasi, reactive oxygen species (ROS) dan nitrik oksida (NO) oleh sel-sel Kupffer, kemudian neutrofil yang direkrut di hati juga memroduksi sitokin-sitokin proinflamasi. Hal tersebut akan menginduksi dan mengakibatkan kerusakan lebih jauh pada sel endotel sinusoid hati maupun hepatosit. Manifestasi klinis gangguan fungsi hati pada sepsis dapat berupa hypoxic hepatitis maupun kolestasis. Pada hypoxic hepatitis akan terjadi kebocoran AST maupun ALT yang menandakan cedera mitokondria dan sel akut. $^{31}$ Berbeda dengan pemeriksaan SGOT pada penelitian ini, pasien sepsis neonatorum lebih sering mengalami peningkatan SGOT yaitu sebesar 71,8\%. SGOT (AST) tidak hanya terdapat pada 
jaringan hati saja oleh karena itu peningkatan SGOT (AST) pada sepsis neonatorum lebih dahulu terjadi dibandingkan SGPT. ${ }^{10,32,33}$ Berdasarkan jenis kelamin pada penelitian ini, gambaran SGPT bayi laki-laki yang mengalami sepsis neonatorum ialah 10 pasien $(21,3 \%)$ dengan kadar SGPT yang meningkat; 6 $(12,8 \%)$ dari 10 tersebut mengalami peningkatan ringan. Selain itu, $3(12,5 \%)$ dari 24 neonatus berjenis kelamin perempuan juga mengalami peningkatan SGPT, yaitu 1 pasien $(4,2 \%)$ mengalami peningkatan ringan dan 2 pasien $(8,3 \%)$ mengalami peningkatan sedang. Sama seperti halnya dengan SGOT, perbedaan persentase jumlah SGPT yang meningkat berdasarkan jenis kelamin dipengaruhi oleh status hormonal. Hormon seks laki-laki yaitu androgen memiliki sifat yang supresif terhadap respon imun yang diperantarai oleh sel, sedangkan hormon seks pada perempuan memiliki efek proteksi yang membuat individu berjenis kelamin perempuan memiliki keuntungan secara alami di bawah pengaruh sepsis. ${ }^{28.29}$ Hill et $\mathrm{al}^{34}$ menyatakan hormon laki-laki atau testosteron secara bertahap mengalami peningkatan pada minggu pertama kehidupan dan tetap tinggi sampai pada tahun pertama. Penelitian Khalil et al ${ }^{9}$ mendapatkan bahwa bayi yang mengalami peningkatan ALT (SGPT) pada penelitiannya berjumlah 57 $(37,3 \%)$ dari 153 neonatus, hampir dua per tiga kasus peningkatan ALT $(64,8 \%)$ terlihat pada hari ketiga onset sepsis neonatorum.

Pasien yang mengalami hipoalbuminemia pada penelitian ini berjumlah 54 bayi (76,1\%). Hipoalbuminemia juga didapatan lebih banyak pada penelitian prospektif dilakukan oleh Wowor et $\mathrm{al}^{35}$ di NICU RSUP Prof Dr. R. D. Kandou Manado tahun 2013 terhadap pasien yang terdiagnosis sepsis, yaitu dari 16 pasien yang mengalami sepsis neonatorum, $12(75,0 \%)$ mengalami hipoalbuminemia sedangkan 4 $(25,0 \%)$ memiliki kadar albumin normal. Penelitian yang dilakukan oleh Yang et al, ${ }^{11}$ melaporkan bahwa dari 32 pasien sepsis neonatorum, sebanyak $27(86,0 \%)$ mengalami hipoalbuminemia. Hasil penelitiam ini memperlihatkan bahwa albumin pada bayi laki-laki yang menderita sepsis neonatorum menunjukkan penurunan yaitu sebanyak $38(80,9 \%)$ dari 47 bayi sedangkan untuk yang berjenis kelamin perempuan, penuruan kadar albumin memiliki persentase sebesar $66,7 \%$. Belum ada penelitian sebelumnya yang membahas gambaran kadar albumin pada sepsis neonatorum berdasarkan jenis kelamin, namun terdapat beberapa penelitian yang membahas kadar albumin berdasarkan jenis kelamin meskipun bukan pada sepsis neonatorum. Penelitian Horowitz et $\mathrm{al}^{36}$ pada pasien anak yang mengalami sakit kritis memperoleh 51 pasien yang mengalami hipoalbuminemia; 25 berjenis kelamin laki-laki dan 26 perempuan. ${ }^{36}$ Singh et $\mathrm{al}^{37}$ juga melakukan penelitian di Nepal yang bertujuan untuk melihat prevalensi hipoalbuminemia pada keseluruhan pasien rawat inap dan rawat jalan berdasarkan usia dan jenis kelamin. Penelitiannya mendapatkan $454(89,72 \%)$ dari 506 pasien laki-laki yang mengalami hipoalbuminemia dan $386(88,12 \%)$ dari 438 pasien perempuan yang juga mengalami hipoalbuminemia. Kedua penelitian tersebut memperlihatkan bahwa prevalensi antara lakilaki dan perempuan yang mengalami penurunan albumin tidak terlalu berbeda, dan alasan terjadinya hipoalbuminemia berdasarkan gender tidak dibahas. ${ }^{37}$ Yang et al $^{11}$ menjelaskan bahwa NO dan ROS yang dihasilkan pada sepsis dapat mengakibatkan inflamasi endotel. Hal ini menyebabkan kadar albumin mengalami penurunan oleh karena meningkatnya permeabilitas vaskular yang mengakibatkan albumin berpindah ke kompartemen interstitial. Kadar albumin yang rendah sering dijadikan acuan untuk menentukan prognosis pada bayi dengan sepsis neonatorum. ${ }^{11}$

Hal lain yang juga berpengaruh terhadap terjadinya penurunan kadar albumin pada pasien sepsis neonatorum dalam tulisan Nesseler et $\mathrm{al}^{7}$ ialah pada saat terjadinya syok sepsis, hati secara aktif berkontribusi terhadap pertahanan pejamu maupun perbaikan jaringan melalui kerja 
sel-sel hati dan juga sel-sel darah. Sel-sel hati akan mengubah jalur metaboliknya terhadap meningkatnya regulasi respon inflamasi, yang kemudian bertanggung jawab dalam peningkatan sintesis protein fase akut, dimana protein fase akut ini diperantarai secara predominan oleh interleukin 6 (IL-6). Perubahan ini membuat teradinya peningkatan $C$-reactive protein, $\alpha$-1-antitrypsin, fibrinogen, protrombin, dan juga kadar haptoglobin, sedangkan produksi hati terhadap albumin, transferin, dan antitrombin mengalami penurunan. Peningkatan regulasi respon fase akut juga menghambat jalur protein $\mathrm{C}$, dan juga perubahan bermakna dalam keseimbangan faktor-faktor koagulasi yang akhirnya mengaktivitas pro-koagulan pada sepsis. ${ }^{7}$

\section{SIMPULAN}

Peningkatan kadar SGOT pada sepsis neonatorum paling sering dalam bentuk peningkatan ringan sedangkan peningkatan kadar SGPT jarang didapatkan pada sepsis neonatorum. Peningkatan ringan SGOT dan SGPT serta penurunan albumin dalam penelitian ini lebih sering dijumpai pada bayi laki-laki.

Pemeriksaan rutin untuk SGOT, SGPT, dan albumin pada pasien sepsis neonatorum perlu dilakukan untuk mencegah komplikasi disfungsi hati akibat sepsis neonatorum.

\section{Konflik Kepentingan}

Penulis menyatakan tidak terdapat konflik kepentingan dalam studi ini.

\section{DAFTAR PUSTAKA}

1. Coetzee M, Mbowane NT, Witt TW. Neonatal sepsis: Highlighting the principles of diagnosis and manage-ment. South African J Child Heal. 2017;11(2):99103.

2. Kardana IM. Incidence and factors associated with mortality of neonatal sepsis. Paediatr Indones. 2011;51(3): 144.

3. World Health Organisation. Causes of deaths among children under 5 years. 2016 [cited 2019 Aug 25]. Available from: http://apps.who.int/gho/data/ view.wrapper.CHILDCODv?lang=en
4. Riset Kesehatan Dasar. Badan Penelitian dan Pengembangan Kesehatan Depar temen Kesehatan Republik Indonesia. Jakarta:2007; p. 278-9.

5. Profil Kesehatan Kota Manado. Departemen Kesehatan Republik Indonesia. Manado, 2017; p. 15.

6. Polin RA, Abman SH, Rowitch DH, Benitz WE, Fox WW. In: Wong HR. Wynn JL, editors. Fetal and Neonatal Physio logy (5th ed). Elsevier, 2017; p. 153652.

7. Nesseler N, Launey Y, Aninat C, Monel F, Malledant Y, Seguin P. Clinical Review: The liver in sepsis. Critical Care. 2012;16:235.

8. Yan J, Li S, Li S. The role of the liver in sepsis. Int Rev Immunol. 2014; 33(6):498.

9. Khalil S, Shah D, Faridi MMA, Kumar A, Mishra K. Prevalence and outcome of hepato-biliary dysfunction in neo natal septicaemia. J Pediatr Gastro enterol Nutr. 2012;54(2):218-22.

10. Adiga US. Gender Differences in Liver Function Tests in Coastal Karnataka. IOSR J Dent Med Sci. 2016;15(8):30-2.

11. Yang C, Liu Z, Tian M, Xu P, Li B, Yang Q, et al. Relationship between serum albumin levels and infections in new born late preterm infants. Med Sci Monit. 2016;22:92.

12. Ozougwu JC. Physiology of the liver. Int J Res Pharm Biosci. 2017;4:17.

13. Kosasih EN, Kosasih AS. Tafsiran Hasil Pemeriksaan Laboratorium Klinik (2nd ed). Jakarta: Karisma Publishing Group, 2008; p. 303-5.

14. Bachtiar KS, Oswari H, Batubara JR, Amir I, Latief A, Firman K. Cholestasis sepsis at neonatology ward and neonatal Intensive Care Unit Cipto Mangunkusumo Hospital 2007: inci dence, mortality rate and associated risk factors. Med J Indones. 2008; 17(2):107-13.

15. Meshram RM, Gajimwar VS, Bhongade SD. Predictors of mortality in outborns with neonatal sepsis: a prospective observational study. Niger Postgrad Med J. 2019; 22(4):216-22.

16. Kumar R, Kumar A, Kumari A, Vema N. Evaluation of perinatal factors in neonatal sepsis at tertiary centre. Int $\mathbf{J}$ Reprod Obstet Gynecol. 2017;6(11): 
4981-5.

17. Roeslani RD, Amir I, Nasrulloh MH, Suryani. Penelitian awal: Faktor risiko pada sepsis neonatorum awitan dini. Sari Pediatr. 2013;14(6):363-8.

18. Rawat S, Rai R, Preeti K, Prashant M, Neeraj $\mathrm{K}$. A review on type, etio logical factors, definition, clinical features, diagnosis management and prevention of neonatal sepsis. J Sci Innov Res. 2013;2(4):802-13.

19. Verma P, Berwal PK, Nagaraj N, Swami S, Jivaji P, Narayan S. Neonatal sepsis: epidemiology, clinical spectrum, recent antimicrobial agents and their antibiotic susceptibility pattern. Int $\mathrm{J}$ Contemp Pediatr. 2015;2(3):176-80.

20. Jaya IG, Suryawan IW, Rahayu PP. Hubungan prematuritas dengan kejadian sepsis neonatorum yang dirawat di ruang perinatologi dan Neonatal Intensive Care Unit (NICU) RSUD Wangaya kota Denpasar. Intisari Sains Medis. 2019;10(1):18.

21. Dini FN, Andayani P, Rosida L. Hubungan antara masa gestasi dan kejadian sepsis neonatorum di RSUD Ulin Banjarmasin Periode Juni 2014-Juni 2015. Berk Kedokt. 2016;12(2):175-85.

22. Shah AA, Patton M, Chishty WH, Hussain A. Analysis of elevated liver enzymes in an acute medical setting: jaundice may indicate increased survival in elderly patients with bacterial sepsis. Saudi J Gastroenterol. 2010;16(4): 2603.

23. Karyana IP, Putra IG, Yanti PV. Kolestasis pada sepsis neonatorum di RSUP Sanglah, Denpasar. Sari Pediatr. 2012;14(4):211-7.

24. Putra PP, Putra IS, Hartawan IN. Perbedaan manifestasi klinis dan laboratorium kolestasis intrahepatal dengan ekstrahepatal pada bayi di RSUP Sanglah Denpasar periode Januari 2015-Desember 2018. Intisari Sains Medis. 2019;10(3):520-3.

25. Rina RM, Oswari H, Amalia P. Urso deoxycholic acid in neonatal sepsisassociated cholestasis. Paediatr
Indones. 2014;54(4):206-12.

26. Pincus MR. Evaluation of liver function. In: Pincus MR, Tierno PM, Gleeson E, Bowne WB, Bluth MH, editors. Henry's Clinical Diagnosis and Management by Laboratory Methods (23rd ed). St Louis: Elsevier, 2017; p. 289.

27. Thapa BR, Walia A. Newer diagnostic tests liver function tests and their inter pretation. Indian J Pediatr. 2007;74.

28. Angele MK, Pratschke S, Hubbard WJ, Chaudry IH. Gender differences in sepsis. Virulence. 2014;5(1):12-9.

29. Dinarshanty DN, Lintang KS, Wibowo S. Kadar TNF- $\alpha$ dan interleukin-6 neonatus dengan klinis sepsis neona torum awitan dini terhadap terjadinya acute liver injury. J Kedokt Brawijaya. 2017;29(3):216-22.

30. Yap CY, Choon AT. Liver function tests (LFTs). Proc Singapore Healthc. 2010;19(1):80.

31. Wang D, Yin Y, Yao Y. Advances in sepsisassociated liver dysfunction. Burn Trauma. 2014;2(3):97.

32. Haghighat M. Approach to liver function tests in children. J Compr Pediatr. 2014;5(2):e17526.

33. Woreta TA, Alqahtani SA. Evaluation of abnormal liver tests. Med Clin NA. 2014;98:1-16.

34. Hill CA, Fitch RH. Sex differences in mechanisms and outcome of neonatal hypoxia-ischemia in rodent models: implications for sex-specific neuro protection in clinical neonatal practice. Neurol Res Int. 2012;1-7.

35. Wowor EE, Rompis J, Wilar R. Hubungan kadar albumin plasma dan gula darah dengan sepsis neonatorum. eBiomedik. 2013;1(1):225-31.

36. Horowitz IN, Tai K. Hypoalbuminemia in critically ill children. Arch Pediatr Adolesc Med. 2017;161(11):1048-52.

37. Singh P, Khan S, Siddiqui AH. Hypoalbuminemia: a hospital based study. Indones $\mathrm{J}$ Biomed Sci. 2012;6(2):40-2. 